\title{
Reinvestigations of the $\mathrm{Li}_{2} \mathrm{O}-\mathrm{Al}_{2} \mathrm{O}_{3}$ system. Part $\mathrm{I}: \mathrm{LiAlO}_{2}$ and $\mathrm{Li}_{3} \mathrm{AlO}_{3}$
}

\author{
Piotr Tabero*, Artur Frąckowiak, Grażyna Dąbrowska \\ West Pomeranian University of Technology Szczecin, Faculty of Chemical Technology and Engineering, Department \\ of Inorganic and Analytical Chemistry, Piastow Avenue 42, 71-065 Szczecin, Poland \\ "Corresponding author: e-mail: ptab@zut.edu.pl
}

\begin{abstract}
Reinvestigations of the $\mathrm{Li}_{2} \mathrm{O}-\mathrm{Al}_{2} \mathrm{O}_{3}$ system focused on the synthesis and properties of $\mathrm{LiAlO}_{2}$ and $\mathrm{Li}_{3} \mathrm{AlO}_{3}$ phases have been performed with the help of XRD and IR measuring techniques and $\mathrm{Li}_{2} \mathrm{CO}_{3}, \mathrm{LiOH} \cdot \mathrm{H}_{2} \mathrm{O}, \mathrm{Al}_{2} \mathrm{O}_{3}-\mathrm{sl}$., $\alpha-\mathrm{Al}_{2} \mathrm{O}_{3}, \mathrm{Al}\left(\mathrm{NO}_{3}\right)_{3} \cdot 9 \mathrm{H}_{2} \mathrm{O}$ and boehmite as reactants. Results of investigations have shown the formation of $\alpha$-, $\beta$-, and $\gamma$ - polymorphs of $\mathrm{LiAlO}_{2}$. It was found that only the use of $\mathrm{LiOH} \cdot \mathrm{H}_{2} \mathrm{O}$ as a reactant yields to $\beta$ - $\mathrm{LiAlO}_{2}$ as a reaction product. On the other hand, it was proved that $\mathrm{Li}_{3} \mathrm{AlO}_{3}$ does not form in the $\mathrm{Li}_{2} \mathrm{O}-\mathrm{Al}_{2} \mathrm{O}_{3}$ system. A new method for the synthesis of $\alpha-\mathrm{LiAlO}_{2}$ was developed, consisting in grinding the mixture of $\mathrm{Li}_{2} \mathrm{CO}_{3}$ and $\mathrm{Al}\left(\mathrm{NO}_{3}\right)_{3} \cdot 9 \mathrm{H}_{2} \mathrm{O}$ and heating the obtained paste at the temperature range of $400-600{ }^{\circ} \mathrm{C}$. The IR spectroscopy was used to characterize obtained phases.
\end{abstract}

Keywords: $\mathrm{Li}_{2} \mathrm{O}-\mathrm{Al}_{2} \mathrm{O}_{3}$ system, $\mathrm{LiAlO}_{2}, \mathrm{Li}_{3} \mathrm{AlO}_{3}, \mathrm{XRD}$, IR.

\section{INTRODUCTION}

Compounds containing lithium have been the subject of comprehensive research for many years due to many different industrial applications, including the production of glass and heat-resistant ceramics ${ }^{1-3}$, luminescent ionizing radiation detectors ${ }^{4,5}$, carbonate fuel cell components ${ }^{6-9}$, carbon dioxide absorbents ${ }^{\mathbf{1 0}}$ and solid electrolytes used for the production of lithium-ion batteries ${ }^{11,12}$. Lithium aluminates are active catalysts for the hydrophosphinization of alkynes, alkenes and carbodiimides ${ }^{13}$. Lithium-based ceramics have been identified as the most important material for obtaining tritium in Test Modules (TBMs) of the International Thermonuclear Experimental Reactor Project, ITER ${ }^{14-18}$.

The literature review has shown that 5 compounds are formed in the two-component system of $\mathrm{Li}_{2} \mathrm{O}-\mathrm{Al}_{2} \mathrm{O}_{3}$ oxides: $\mathrm{Li}_{5} \mathrm{AlO}_{4}, \mathrm{Li}_{3} \mathrm{AlO}_{3}, \mathrm{LiAl}_{2} \mathrm{O}_{3.5}, \mathrm{LiAlO}_{2}$ and $\mathrm{LiAl}_{5} \mathrm{O}_{8}$. Hatch $^{19}$ suggests that limited or continuous solid solutions may form between $\mathrm{LiAl}_{5} \mathrm{O}_{8}$ and $\gamma-\mathrm{Al}_{2} \mathrm{O}_{3}$. So far, no phase diagram of the $\mathrm{Li}_{2} \mathrm{O}-\mathrm{Al}_{2} \mathrm{O}_{3}$ system has been developed in the entire concentration range of the components. There are two versions of the phase diagram of the system in the range of $\mathrm{LiAlO}_{2}-\mathrm{Al}_{2} \mathrm{O}_{3}{ }^{20,21}$, which show that one $\mathrm{LiAl}_{5} \mathrm{O}_{8}$ compound is formed. In none of these works, there was any information about the formation of the $\mathrm{LiAl}_{2} \mathrm{O}_{35}$ compound, mentioned by M. Kriens and co-authors ${ }^{22}$. There are three versions of the phase diagram of the $\mathrm{Li}_{2} \mathrm{O}-\mathrm{Al}_{2} \mathrm{O}_{3}$ system, developed based on thermodynamic data available in the literature ${ }^{23-25}$.

Despite numerous studies on the $\mathrm{Li}_{2} \mathrm{O}-\mathrm{Al}_{2} \mathrm{O}_{3}$ system, there is still controversy about the number and type of phases formed in it, methods of their preparation and properties ${ }^{19-55}$. Therefore, our work aimed to verify the literature data on the $\mathrm{Li}_{2} \mathrm{O}-\mathrm{Al}_{2} \mathrm{O}_{3}$ system. The first part of our investigations was focused on the $\mathrm{LiAlO}_{2}$ and $\mathrm{Li}_{3} \mathrm{AlO}_{3}$ phases.

The $\mathrm{LiAlO}_{2}$ compound has four polymorphic modifications ${ }^{26-46}$ : hexagonal $\alpha^{26-29}$, orthorhombic $\beta^{30,31}$, tetragonal $\gamma^{32}$ and the $\delta$ - $\mathrm{LiAlO}_{2}$ formed at pressures above 9 $\mathrm{GPa}^{33}$. High-pressure studies carried out by Lei et al. ${ }^{34}$ showed that the monoclinic form of $\beta$ ' $-\mathrm{LiAlO}_{2}$ obtained by Cheng ${ }^{35}$ under the pressure of $1.8 \mathrm{GPa}$ is in fact the orthorhombic modification of $\beta-\mathrm{LiAlO}_{2}$ and it can be obtained already at the pressure of $0.8 \mathrm{GPa}$ and tem- perature $623 \mathrm{~K}$. On the other hand, the cubic form of $\mathrm{LiAlO}_{2}$ described by Debray and Hardy ${ }^{36}$ is in fact the teragonal $\gamma-\mathrm{LiAlO}_{2}$. Table 1 presents the basic crystallographic data of polymorphic modifications of $\mathrm{LiAlO}_{2}$.

The tetragonal $\gamma-\mathrm{LiAlO}_{2}$ is considered to be the most thermodynamically stable polymorphic modification of $\mathrm{LiAlO}_{2}$ and it is considered to be a potential material for obtaining tritium for the purposes of nuclear fusion, substrates for epitaxial growth of II-V semiconductors such as $\mathrm{GaN}$, components for the production of liquid carbonate fuel cells or radiation dosimeters ${ }^{9}, 12,15-17,37-39$. In recent years, however, attention has been paid to the hexagonal form of $\alpha-\mathrm{LiAlO}_{2}{ }^{38-44}$. It has been shown that at the operating temperature of the fuel cell equal to $650^{\circ} \mathrm{C}$, the alpha variety is more stable than the gamma variety ${ }^{41}$. The $\alpha-\mathrm{LiAlO}_{2}$ polymorph is also considered as a component for the production of electrode protective layers in lithium batteries ${ }^{40-42}$. A necessary condition for the use of $\alpha-\mathrm{LiAlO}_{2}$, however, is to obtain a product containing nanometric grain size.

The literature review shows that the $\alpha-\mathrm{LiAlO}_{2}$ formed at temperatures not exceeding $600{ }^{\circ} \mathrm{C}$ is nanocrystalline, however, it is most often contaminated with substrates or by-products of the synthesis reaction ${ }^{45,46}$. The large broadening of the diffraction reflections of the $\alpha-\mathrm{LiAlO}_{2}$ obtained in such conditions is related to the presence of crystallites with dimensions of the order of 7-15 nm and a strong structure defect. SEM and TEM microscopic studies revealed the presence of dislocations and inclusions of spinel-like fragments or amorphous areas in the $\alpha-\mathrm{LiAlO}_{2}$ samples tested ${ }^{6}$. On the other hand, at temperatures above $650{ }^{\circ} \mathrm{C}$, a slowly progressing phase transition under these conditions begins, leading to the tetragonal $\gamma-\mathrm{LiAlO}_{2}{ }^{27,40}$.

The conducted literature review showed that the authors of the studies disagreed as to the temperature of phase transitions and the thermal stability of the $\mathrm{LiAlO}_{2}$ polymorphs. Lejus ${ }^{20,47}$, found that at $900{ }^{\circ} \mathrm{C}, \alpha-\mathrm{LiAlO}_{2}$ undergoes a reversible transformation to the hightemperature $\gamma$ polymorph however, the transformation from $\gamma$ to $\alpha$ is very slow. $\mathrm{LiAlO}_{2}$ melts at $1700{ }^{\circ} \mathrm{C}$, but at temperatures higher than $1300^{\circ} \mathrm{C}$, it decomposes into $\mathrm{LiAl}_{5} \mathrm{O}_{8}$ and $\mathrm{Li}_{2} \mathrm{O}$, caused by the high volatility of lithium oxide. According to Lehmann et al. ${ }^{27}$ slow irreversible 
transformation of $\alpha \rightarrow \gamma-\mathrm{LiAlO}_{2}$ occurs at temperatures above $600{ }^{\circ} \mathrm{C}$. Hummel and co-workers ${ }^{48}$ claim that the $\alpha$ phase undergoes a rapid phase transition at the temperature of $1200-1300{ }^{\circ} \mathrm{C}$, and the melting point of $\mathrm{LiAlO}_{2}$ is equal to $1610 \pm 15{ }^{\circ} \mathrm{C}$.

Isupov et al. ${ }^{49}$ investigated the effect of the gaseous atmosphere on the type of $\mathrm{LiAlO}_{2}$ modification produced using gibbsite and $\mathrm{Li}_{2} \mathrm{CO}_{3}$ mixture. They showed that during synthesis at $800{ }^{\circ} \mathrm{C}$ in air with typical partial water pressure of $1300 \mathrm{~Pa}$ forms $\alpha-\mathrm{LiAlO}_{2}$ contaminated with small amounts of $\gamma-\mathrm{LiAlO}_{2}$. Synthesis in helium with water partial pressure not exceeding $4 \mathrm{~Pa}$ form both modifications in similar amounts but in vacuum with water pressure of $0.1 \mathrm{~Pa}$ mostly $\gamma-\mathrm{LiAlO}_{2}$ is formed.

The structure of the $\alpha-\mathrm{LiAlO}_{2}{ }^{30}, \beta-\mathrm{LiAlO}_{2}{ }^{31}, \gamma-\mathrm{LiAlO}_{2}{ }^{33}$ and $\delta$ - $\mathrm{LiAlO}^{24}$ is known. The crystal lattice of the hexagonal layered $\alpha-\mathrm{LiAlO}_{2}$ and the high-pressure tetragonal $\delta$ - $\mathrm{LiAlO}_{2}$ are deformed variants of the $\mathrm{NaCl}$ structure with ordered $\mathrm{Li}^{+}$and $\mathrm{Al}^{3+}$ ions in the octahedral sites. In the structure of $\gamma-\mathrm{LiAlO}_{2}{ }^{33} \mathrm{LiO}_{4}$ and $\mathrm{AlO}_{4}$ tetrahedra connected by common corners form layers that connect to adjacent layers by common edges. In turn, the $\beta$ - $\mathrm{LiAlO}_{2}$ crystal lattice with a deformed wurtzite structure is built of $\mathrm{LiO}_{4}$ and $\mathrm{AlO}_{4}$ tetrahedrons connected via common corners ${ }^{31}$.

IR spectra of $\alpha-\mathrm{LiAlO}_{2}, \beta-\mathrm{LiAlO}_{2}$ and $\gamma-\mathrm{LiAlO}_{2}$ are known $^{32,47,50-52 .}$.

La Ginestra and co-workers ${ }^{53}$, as a result of heating at $400{ }^{\circ} \mathrm{C}$ for 500 hours of the mixture of $\gamma-\mathrm{Al}_{2} \mathrm{O}_{3}$ and $\mathrm{Li}_{2} \mathrm{O}_{2}$ obtained the $\mathrm{Li}_{3} \mathrm{AlO}_{3}$ phase and presented the powder diffraction pattern of this compound. The authors did not manage to obtain single-phase $\mathrm{Li}_{3} \mathrm{AlO}_{3}$ sample, but only a mixture containing about $40 \%$ of unreacted reagents. According to the researchers, the $\mathrm{Li}_{3} \mathrm{AlO}_{3}$ is metastable and above $420{ }^{\circ} \mathrm{C}$ it decomposes with the release of $\alpha-\mathrm{LiAlO}_{2}$ and $\mathrm{Li}_{5} \mathrm{AlO}_{4}{ }^{53}$. The authors of the study failed to obtain the $\mathrm{Li}_{3} \mathrm{AlO}_{3}$ phase with the use of $\mathrm{Li}_{2} \mathrm{CO}_{3}, \mathrm{LiNO}_{3}$ and $\mathrm{Li}_{2} \mathrm{O}^{53}$. The existence of the $\mathrm{Li}_{3} \mathrm{AlO}_{3}$ compound was also postulated by Kroger and Fingars ${ }^{54}$ and Fedorov and Shamari ${ }^{55}$, but the compound was not characterized by them.

\section{EXPERIMENTAL}

The following materials were used for the research: $\mathrm{Li}_{2} \mathrm{CO}_{3}$, a.p. (POCh, Poland), $\mathrm{LiOH} \cdot \mathrm{H}_{2} \mathrm{O}$ (Loba Chemie, Austria), $\mathrm{Al}_{2} \mathrm{O}_{3}$ pure, sintered, denoted as $\mathrm{Al}_{2} \mathrm{O}_{3}$-sl (POCh, Poland), boehmite- $\gamma-\mathrm{AlOOH}$ (POCH, Poland) and $\mathrm{Al}\left(\mathrm{NO}_{3}\right)_{3} \cdot 9 \mathrm{H}_{2} \mathrm{O}$ a.p. (POCH. Poland). $\alpha-\mathrm{Al}_{2} \mathrm{O}_{3}$ was obtained by sintering $\mathrm{Al}_{2} \mathrm{O}_{3}$-sl at $1200{ }^{\circ} \mathrm{C}$ for 4 hours.
The syntheses of $\mathrm{Li}_{3} \mathrm{AlO}_{3}$ and $\mathrm{LiAlO}_{2}$ were carried out using a conventional solid-state reaction method, analogous to that presented in ${ }^{56-59}$.

The substrates weighed in suitable proportions were homogenized in an agate mortar and calcinated in the temperature range of $400-1200{ }^{\circ} \mathrm{C}$ in $24 \mathrm{~h}$ stages. The samples were heated in the furnace FCF 3.5/1350 (Czylok, Poland). Temperatures of calcination of samples were estimated basing on literature data concerning $\mathrm{Li}_{2} \mathrm{O}$ $\mathrm{Al}_{2} \mathrm{O}_{3}$ system $^{19,21,23, ~ 29, ~ 47, ~ 48, ~} 55$.

In the frames of this work new method of $\mathrm{LiAlO}_{2}$ synthesis was developed. Lithium carbonate and aluminum nitrate $(\mathrm{V})$ nonahydrate weighed in stochiometric proportions were ground in a mortar until the release of $\mathrm{CO}_{2}$ bubbles ceases. The semi-finished product thus obtained was in the form of a paste. Subsequently, the paste obtained was heated in an air atmosphere in the temperature range of $400-600{ }^{\circ} \mathrm{C}$, then, after taking it out of the furnace, it was cooled to room temperature in desiccator, ground in a mortar and subjected to Xray investigations.

The phase composition of samples was investigated by using XRD method and identified by powder diffraction patterns of obtained samples recorded with the aid of the diffractometer EMPYREAN II, (PANalytical, The Nederlands) using the CuKa radiation with a graphite monochromator with the help of Highscore + software and PDF4+ICDD database. The powder diffraction patterns of selected phases were indexed using the REFINEMENT program of DHN/PDS package.

The IR spectra were recorded on the SPECORD M 80 spectrometer (Carl Zeiss, Jena, Germany). The measurements were made within the wavenumber range of $4000-200 \mathrm{~cm}^{-1}$. The infrared spectra were made by pelleting a sample with $\mathrm{KBr}$ in the weight ratio of 1:300.

The mean crystallite size of selected samples was calculated using the Scherrer formula:

$D_{h k l}=\frac{k \cdot \lambda}{\beta \cdot \cos \theta}$

where: $\beta$ - the half-width of the reflex (hkl) [rad],

$\mathrm{D}_{\mathrm{hkl}}$ - mean crystallite size in the direction perpendicular to the plane (hkl) $[\AA]$,

$\lambda$ - wavelength of the X-ray radiation used, $\lambda=1.5406[\AA]$,

$\mathrm{k}$ - Scherrer's constant equal to $\mathrm{k}=0.94$,

$\theta-$ reflection angle, related to the reflection (hkl) $\left[{ }^{\circ}\right]$.

\section{RESULTS AND DISCUSSION}

Transition modifications of alumina such as $\gamma_{-}, \eta-$, $\delta$ - and $\theta-\mathrm{Al}_{2} \mathrm{O}_{3}$ obtained in the temperature range

Table 1. Basic crystallographic data of $\alpha-\mathrm{LiAlO}_{2}, \beta-\mathrm{LiAlO}_{2}, \gamma-\mathrm{LiAlO}_{2}$ and $\delta-\mathrm{LiAlO}_{2}$ phases, where CS-crystal system: O - orthorhombic, T - tetragonal, $\mathrm{H}$ - hexagonal HP(GPa)-modification obtain under high pressure equal to (GPa), SG (no.) - space group and its number; D - distorted structure, TW - this work

\begin{tabular}{|c|c|c|c|c|c|c|c|c|}
\hline \multirow{2}{*}{ Formula } & \multirow{2}{*}{$\begin{array}{c}\mathrm{Li}_{2} \mathrm{O} \\
{[\% \mathrm{~mol}]}\end{array}$} & \multirow{2}{*}{$\begin{array}{l}\text { Structure } \\
\text { type }\end{array}$} & \multirow{2}{*}{ CS } & \multirow{2}{*}{ SG (no.) } & \multicolumn{3}{|c|}{ Unit cell parameters } & \multirow{2}{*}{ Ref } \\
\hline & & & & & $\mathrm{a}[\AA]$ & $\mathrm{b}[\AA]$ & $c[\AA]$ & \\
\hline$\alpha-\mathrm{LiAlO}_{2}$ & 50.0 & $\alpha-\mathrm{NaFeO}_{2}$ & $\mathrm{H}$ & R-3m (166) & 2.7993 & 2.793 & 14.180 & [29] \\
\hline$\alpha-\mathrm{LiAlO}_{2}$ & 50.0 & & $\mathrm{H}$ & & 2.8020 & 2.8020 & 14.2246 & TW \\
\hline$\beta-\mathrm{LiAlO}_{2}$ & 50.0 & & $\mathrm{O}$ & & 5.272 & 6.299 & 4.903 & TW \\
\hline $\mathrm{Y}-\mathrm{LiAlO}_{2}$ & 50.0 & $\mathrm{Y}$-LiAlO 2 & $\mathrm{~T}$ & $\mathrm{P}_{4} 2_{1} 2(90)$ & 5.1687 & 5.1687 & 6.2679 & [33] \\
\hline $\mathrm{Y}-\mathrm{LiAlO}_{2}$ & 50.0 & & $\mathrm{~T}$ & & 5.1724 & 5.1724 & 6.2756 & TW \\
\hline$\delta$ - $\mathrm{LiAlO}_{2}$ & 50.0 & $\begin{array}{c}\text { D NaCl HP } \\
(9 \mathrm{GPa})\end{array}$ & $\mathrm{T}$ & 14,/amd (141) & 3.8866 & 3.8866 & 8.3001 & [34] \\
\hline
\end{tabular}


$400-1000{ }^{\circ} \mathrm{C}$ have a defective spinel structure based on a cubic close packed lattice of oxide ions ${ }^{\mathbf{6 0}, \mathbf{6 1}}$. For this reason, the powder diffraction patterns of individual modifications reported in the literature are similar to each other (similar $d_{h k l}$ values). It is very difficult to clearly identify these transition alumina. In this work, when writing about this type of phases, we will use the common symbol $\mathrm{Al}_{2} \mathrm{O}_{3}$-sl (spinel like).

In the first stage of investigations synthesis of $\mathrm{LiAlO}_{2}$ was carried out using $\mathrm{Li}_{2} \mathrm{CO}_{3}$ and $\alpha-\mathrm{Al}_{2} \mathrm{O}_{3}, \mathrm{Al}_{2} \mathrm{O}_{3}$-sl and boehmite as aluminum precursors. Figures $1 \mathrm{~A}$ and $1 \mathrm{~B}$ show fragments of powder diffractograms of the reaction mixtures prepared with the use of $\mathrm{Al}_{2} \mathrm{O}_{3}$-sl and $\mathrm{Li}_{2} \mathrm{CO}_{3}$ (Fig. 1A) or of $\alpha-\mathrm{Al}_{2} \mathrm{O}_{3}$ and $\mathrm{Li}_{2} \mathrm{CO}_{3}$ (Fig. 1B) with the compositions corresponding to the $\mathrm{LiAlO}_{2}$ phase, and samples recorded after successive heating stages in the temperature range of $450-1000{ }^{\circ} \mathrm{C}$.
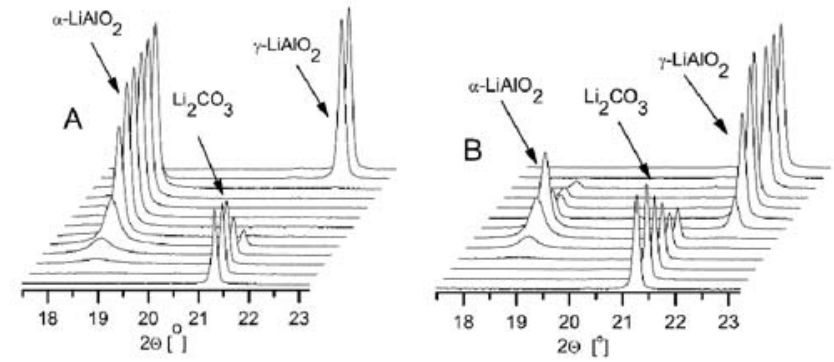

Figure 1. Fragments of the powder diffractograms of the reaction mixture prepared with the use of $\mathrm{Al}_{2} \mathrm{O}_{3}$-sl and $\mathrm{Li}_{2} \mathrm{CO}_{3}$ (A) and with the use of $\alpha-\mathrm{Al}_{2} \mathrm{O}_{3}$ and $\mathrm{Li}_{2} \mathrm{CO}_{3}$ (B) with the composition corresponding to the $\mathrm{LiAlO}_{2}$ phase and samples recorded after successive heating stages in the temperature range of $450-1000{ }^{\circ} \mathrm{C}$

During the heating stage at $450{ }^{\circ} \mathrm{C}$, almost all boehmite used in the synthesis decomposed to form $\mathrm{Al}_{2} \mathrm{O}_{3}$-sl, and the further synthesis process was carried out in this sample with the use of in situ formed precursor. A single-phase sample containing $\alpha-\mathrm{LiAlO}_{2}$ was obtained using boehmite and $\mathrm{Al}_{2} \mathrm{O}_{3}$-sl after the heating stage at the temperature of $700{ }^{\circ} \mathrm{C}$. In both cases, the $\alpha-\mathrm{LiAlO}_{2}$ modification appeared in reaction mixtures after a heating stage at $500{ }^{\circ} \mathrm{C}$. Pure $\alpha-\mathrm{LiAlO}_{2}$ obtained after sintering at $700{ }^{\circ} \mathrm{C}$ was stable up to the temperature of $900{ }^{\circ} \mathrm{C}$, at which the slow phase change leading to $\gamma-\mathrm{LiAlO}_{2}$ began. However, a single-phase sample of $\gamma-\mathrm{LiAlO}_{2}$ was obtained only after the heating stage at $1000{ }^{\circ} \mathrm{C}$. The reaction of $\mathrm{LiAlO}_{2}$ synthesis with the use of corundum was much slower. During it, the $\alpha-\mathrm{LiAlO}_{2}$ modification appeared in the reaction mixture after a heating stage at $550{ }^{\circ} \mathrm{C}$, but we failed to obtain a single-phase sample of $\alpha-\mathrm{LiAlO}_{2}$. On the other hand small amounts of $\gamma-\mathrm{LiAlO}_{2}$ were detected after the heating stage at $650{ }^{\circ} \mathrm{C}$ while the pure $\gamma-\mathrm{LiAlO}_{2}$ was obtained after the heating stage at $950{ }^{\circ} \mathrm{C}$ (Fig. 1A and 1B).

In the frames of this work new method of $\mathrm{LiAlO}_{2}$ synthesis was developed using a mixture of aluminum nitrate $(\mathrm{V})$ and lithium carbonate as reactants. Grinding of the $\mathrm{Li}_{2} \mathrm{CO}_{3}$ and $\mathrm{Al}\left(\mathrm{NO}_{3}\right)_{3} \cdot 9 \mathrm{H}_{2} \mathrm{O}$ solids initiates the reaction between them, as evidenced by $\mathrm{CO}_{2}$ gas bubbles intensively emitted during the grinding of the reagents in the mortar. The reaction is probably favored by a very large number of crystallization water molecules contained in the crystal lattice of aluminum nitrate(V) nanohydrate, which, released during intense grinding, enables the aluminum nitrate(V) hydrolysis reaction leading to strong acidification of the reaction medium and initiates the decomposition of $\mathrm{Li}_{2} \mathrm{CO}_{3}$. The mechanism of this process is currently being researched and the results will be presented in the next paper. The paste obtained after the evolution of $\mathrm{CO}_{2}$ bubbles had ceased was then heated in a furnace under an air atmosphere in the temperature range of $400-600{ }^{\circ} \mathrm{C}$. Figure 2 shows the diffractograms recorded after the successive stages of heating the obtained paste.

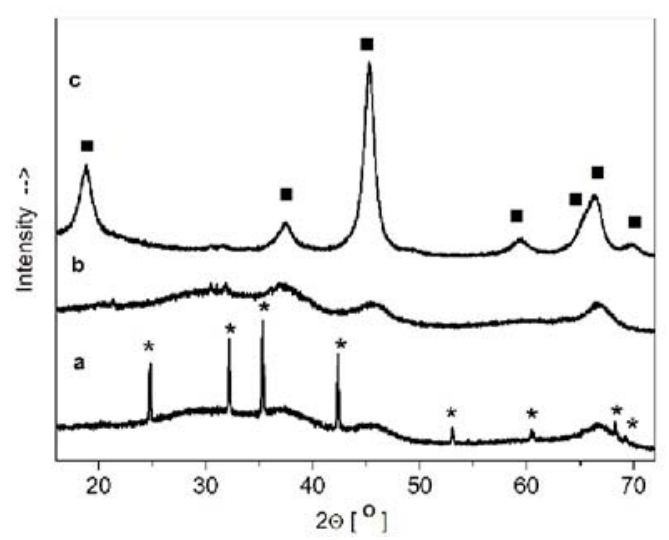

Figure 2. Powder diffraction patterns recorded during the synthesis of $\alpha-\mathrm{LiAlO}_{2}$ with a new method using $\mathrm{Li}_{2} \mathrm{CO}_{3}$ and $\mathrm{Al}\left(\mathrm{NO}_{3}\right)_{3} \cdot 9 \mathrm{H}_{2} \mathrm{O}$ after the heating steps at the following temperatures: a $-400{ }^{\circ} \mathrm{C} \times 30 \mathrm{~min}$, $\mathrm{b}-400{ }^{\circ} \mathrm{C}$ x d and $\mathrm{c}-600{ }^{\circ} \mathrm{C}$ x $30 \mathrm{~min} .{ }^{*}-$ means $\mathrm{LiNO}_{3}, \mathbf{\square}-$ means $\alpha-\mathrm{LiAlO}_{2}$

Single-phase sample containing $\alpha-\mathrm{LiAlO}_{2}$ was obtained after 30 minutes of heating at $600{ }^{\circ} \mathrm{C}$, while the synthesis with $\mathrm{Al}_{2} \mathrm{O}_{3}$-sl and $\mathrm{Li}_{2} \mathrm{CO}_{3}$ required heating the reactants at $700{ }^{\circ} \mathrm{C}$. Lithium nitrate(V) melts at $255^{\circ} \mathrm{C}$, and boils and decomposes at $600{ }^{\circ} \mathrm{C}$. The presence of $\mathrm{LiNO}_{3}$ reflections (PDF 04-010-5519) on the diffractogram of the reaction mixture after the heating step at $400{ }^{\circ} \mathrm{C}$ for 30 minutes shows that even molten $\mathrm{LiNO}_{3}$ slowly reacts with the components of the reaction mixture. The $\alpha-\mathrm{LiALO}_{2}$ obtained at the temperature of $600{ }^{\circ} \mathrm{C}$ x 30 min was characterized by strongly broadened diffraction reflections, and the average size of crystallites in this preparation determined by the Scherrer method was equal to $75 \AA$. This value is consistent with the results of the research presented in ${ }^{6}$, where the effect of calcination time of the $\alpha-\mathrm{LiAlO}_{2}$ sample at $600{ }^{\circ} \mathrm{C}$ on the size of crystallites was analyzed. The reason for the significant broadening of diffraction reflections is, inter alia, a high concentration of defects in the crystal lattice of $\alpha-\mathrm{LiAlO}_{2}$ obtained at low temperatures ${ }^{6}$. It should be mentioned, however, that regardless of the type of metal precursors used in the synthesis of $\alpha-\mathrm{LiAlO}_{2}$, the reflexes of this phase were considerable broadened. The crystallite size determined by the Scherrer method during the synthesis of $\alpha-\mathrm{LiAlO}_{2}$ with the use of $\mathrm{Li}_{2} \mathrm{CO}_{3}$ and boehmite increased gradually with the increase of temperature from $101 \AA\left(600{ }^{\circ} \mathrm{C} \times 24 \mathrm{~h}\right)$ through $389 \AA$ $\left(700^{\circ} \mathrm{C} \times 24 \mathrm{~h}\right)$ to $406 \AA\left(850{ }^{\circ} \mathrm{C} \times 24 \mathrm{~h}\right)$.

The literature review showed that the $\mathrm{Li}_{3} \mathrm{AlO}_{3}$ phase obtained by La Ginestra et al. ${ }^{\mathbf{5 3}}$ is relatively poorly 
studied. Taking into account the comments of the authors of the work ${ }^{53}$, an attempt was made to obtain the $\mathrm{Li}_{3} \mathrm{AlO}_{3}$ phase by heating a mixture of $\mathrm{LiOH} \cdot \mathrm{H}_{2} \mathrm{O}$ and $\mathrm{Al}_{2} \mathrm{O}_{3}$-sl with a composition corresponding to the $\mathrm{Li}_{3} \mathrm{AlO}_{3}$ phase in the temperature range of $400-500{ }^{\circ} \mathrm{C}$. The diffractograms recorded after the first and second heating steps at $400{ }^{\circ} \mathrm{C}$ for $72 \mathrm{~h}$ resembled that of the $\mathrm{Li}_{3} \mathrm{AlO}_{3}$ phase presented by Ginestera. However, X-ray phase analysis showed that the samples obtained at $400{ }^{\circ} \mathrm{C}$ were not single-phase and contained a mixture of $\mathrm{LiOH}$ (PDF 00-032-0564), $\mathrm{Li}_{2} \mathrm{CO}_{3}$ and $\beta-\mathrm{LiAlO}_{2}$ (PDF 00-0330785) (Fig. 3).

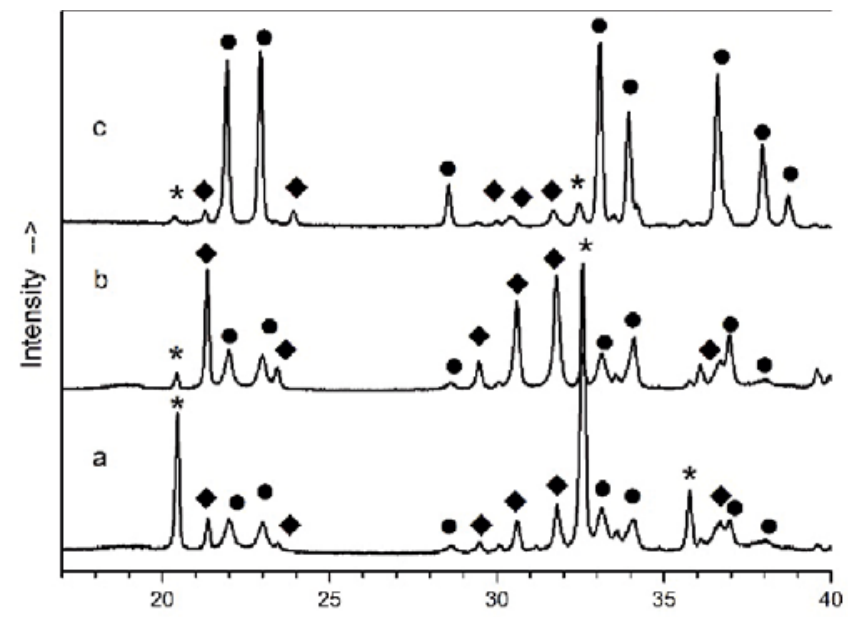

Figure 3. Fragments of the powder diffraction patterns recorded after successive stages of heating the mixture of $\mathrm{LiOH} \cdot \mathrm{H}_{2} \mathrm{O}$ and $\mathrm{Al}_{2} \mathrm{O}_{3}$-sl with the composition corresponding to the formula $\mathrm{Li}_{3} \mathrm{AlO}_{3}$ : a -1 st stage $400{ }^{\circ} \mathrm{C} \times 72 \mathrm{~h}, \mathrm{~b}-2$ nd stage $400{ }^{\circ} \mathrm{C} \times 72 \mathrm{~h}$ and $\mathrm{c}-3 \mathrm{rd}$ stage $-500{ }^{\circ} \mathrm{C} \times 72 \mathrm{~h}$, where ${ }^{*}-\mathrm{LiOH}$, - $\beta-\mathrm{LiAlO}_{2}$ and $-\mathrm{Li}_{2} \mathrm{CO}_{3}$

However, individual reflections from the $\mathrm{Li}_{3} \mathrm{AlO}_{3}$ diffractogram presented by Ginestera were shifted by $0.01-0.20$ degrees towards higher 2 Theta angles in relation to the position on our diffractograms and data contained in PDF cards of $\mathrm{LiOH}, \mathrm{Li}_{2} \mathrm{CO}_{3}$ and $\beta-\mathrm{LiAlO}_{2}$. Therefore, the conducted research shows that the phase with the formula $\mathrm{Li}_{3} \mathrm{AlO}_{3}$ is not formed. According to the literature data, $\mathrm{LiOH}$ identified in reaction mixtures may be formed as a result of the reaction of $\mathrm{Li}_{2} \mathrm{O}$ with water contained in the air. $\mathrm{LiOH}$ is also formed as a result of dehydration of $\mathrm{LiOH} \cdot \mathrm{H}_{2} \mathrm{O}$ in the temperature range $90-200{ }^{\circ} \mathrm{C}$ and then in the temperature range $420-550{ }^{\circ} \mathrm{C}$ it decomposes with the release of $\mathrm{Li}_{2} \mathrm{O}^{49}$. The presence of $\mathrm{Li}_{2} \mathrm{CO}_{3}$ in the obtained samples can also be explained because both $\mathrm{LiOH} \cdot \mathrm{H}_{2} \mathrm{O}$ and $\mathrm{LiOH}$ have the ability to bind large amounts of $\mathrm{CO}_{2}$ from the air to form $\mathrm{Li}_{2} \mathrm{CO}_{3}{ }^{49}$. After another heating step at $500{ }^{\circ} \mathrm{C}$ for $72 \mathrm{~h}$, the content of $\beta-\mathrm{LiAlO}_{2}$ in the sample increased significantly. This fact prompted us to try to synthesize $\beta-\mathrm{LiAlO}_{2}$ using a stoichiometric mixture of $\mathrm{LiOH} \cdot \mathrm{H}_{2} \mathrm{O}$ and $\mathrm{Al}_{2} \mathrm{O}_{3}$-sl. Figure 4 shows the diffractograms of the sample with the composition $\mathrm{LiAlO}_{2}$ after subsequent stages of heating. The analysis of the XRD test results showed that the reaction mixture after the first stage of heating at $500{ }^{\circ} \mathrm{C}$ for $72 \mathrm{~h}$ contained $\beta-\mathrm{LiAlO}_{2}$ as the main component, accompanied by $\mathrm{Li}_{2} \mathrm{CO}_{3}$ and $\alpha-\mathrm{LiAlO}_{2}$ in much smaller amounts. After the second stage of heating at $650{ }^{\circ} \mathrm{C}$ for 24 hours, the obtained product contained a mixture of $\alpha$ - and $\beta-\mathrm{LiAO}_{2}$, and the intensity of reflections characteristic of $\alpha-\mathrm{LiAO}_{2}$ increased. The sample after the heating step at $700{ }^{\circ} \mathrm{C}$ for $24 \mathrm{~h}$ contained $\gamma-\mathrm{LiAlO}_{2}$ as the main component, accompanied by lower amounts of $\alpha$ - and $\beta-\mathrm{LiAlO}_{2}$.

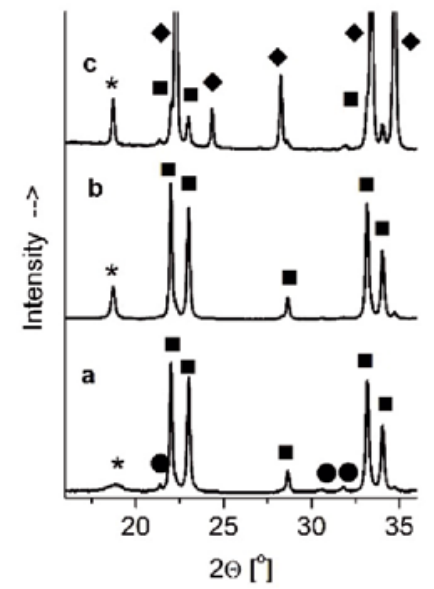

Figure 4. Fragments of the powder diffraction patterns recorded after successive stages of heating the mixture of $\mathrm{LiOH} \cdot \mathrm{H}_{2} \mathrm{O}$ and $\mathrm{Al}_{2} \mathrm{O}_{3}$-sl with the composition corresponding to the formula $\mathrm{LiAlO}_{2}$ : a -1 st stage $500{ }^{\circ} \mathrm{C} \times 72 \mathrm{~h}, \mathrm{~b}-2$ nd stage $650{ }^{\circ} \mathrm{C} \times 72 \mathrm{~h}$ and $\mathrm{c}-3 \mathrm{rd}$ stage- $700{ }^{\circ} \mathrm{C}$ x $72 \mathrm{~h}$, where ${ }^{*}-\alpha-\mathrm{LiAlO}_{2}$, - $\beta-\mathrm{LiAlO}_{2}, \boldsymbol{-} \gamma-\mathrm{LiAlO}_{2}$ and $-\mathrm{Li}_{2} \mathrm{CO}_{3}$

The conducted research indicates that the use of $\mathrm{LiOH}$. $\mathrm{H}_{2} \mathrm{O}$ as a lithium precursor promotes the formation of $\beta$ - $\mathrm{LiAlO}_{2}$. However, while striving to eliminate lithium carbonate from the reaction mixture by increasing the reaction temperature, the content of the $\alpha-\mathrm{LiAlO}_{2}$ is simultaneously increased, and above $650{ }^{\circ} \mathrm{C} \beta-\mathrm{LiAlO}_{2}$ undergoes a phase transition to $\gamma-\mathrm{LiAlO}_{2}$. Currently, research is conducted to obtain a single-phase $\beta-\mathrm{LiAlO}_{2}$ sample and the results will be published soon.

The powder diffractograms of the $\beta-\mathrm{LiAlO}_{2}, \gamma-\mathrm{LiAlO}_{2}$ and $\alpha-\mathrm{LiAlO}_{2}$ phases were indexed using the Refinement program. The calculated values of the unit cell parameters are shown in Table 1. In the case of $\beta-\mathrm{LiAO}_{2}$, the results of the powder diffractogram pattern indexing are presented in Table 2.

Table 2. The result of the indexing of X-ray powder diffraction pattern of $\beta-\mathrm{LiAlO}_{2}$ obtained in this work

\begin{tabular}{|l|c|c|c|c|}
\hline Lp. & $\mathrm{d}_{\exp }[\mathrm{nm}]$ & $\mathrm{d}_{\mathrm{cal}}[\mathrm{nm}]$ & $(\mathrm{hkl})$ & $\mathrm{l} / \mathrm{I}_{0}[\%]$ \\
\hline 1. & 4.0479 & 4.0431 & 110 & 98 \\
\hline 2. & 3.8737 & 3.8693 & 011 & 86 \\
\hline 3. & 3.1218 & 3.1194 & 111 & 16 \\
\hline 4. & 2.7050 & 2.7039 & 120 & 100 \\
\hline 5. & 2.6377 & 2.6362 & 200 & 55 \\
\hline 6. & 2.4532 & 2.4516 & 002 & 59 \\
\hline 7. & 2.3690 & 2.3678 & 121 & 25 \\
\hline 8. & 2.3237 & 2.3219 & 201 & 10 \\
\hline 9. & 2.1787 & 2.1786 & 211 & 4 \\
\hline 10. & 2.0967 & 2.0963 & 112 & 6 \\
\hline 11. & 1.9299 & 1.9302 & 031 & 3 \\
\hline 12. & 1.8149 & 1.8126 & 131 & 22 \\
\hline 13. & 1.7958 & 1.7953 & 202 & 9 \\
\hline 14. & 1.7270 & 1.7265 & 212 & 2 \\
\hline 15. & 1.6419 & 1.6424 & 230 & 1 \\
\hline 16. & 1.5997 & 1.6001 & 311 & 4 \\
\hline 17. & 1.5745 & 1.5748 & 040 & 5 \\
\hline 18. & 1.5343 & 1.5347 & 320 & 34 \\
\hline 19. & 1.3980 & 1.3987 & 123 & 16 \\
\hline 20. & 1.3892 & 1.3891 & 203 & 6 \\
\hline
\end{tabular}


To know better properties of obtained phases IR spectra of $\gamma-\mathrm{LiAlO}_{2}, \beta-\mathrm{LiAlO}$ and $\alpha-\mathrm{LiAlO}_{2}$ were recorded. Analysis of the number and positions of absorption bands recorded in their IR spectra has shown good agreement with literature data ${ }^{32,}$ 47, 50-52.

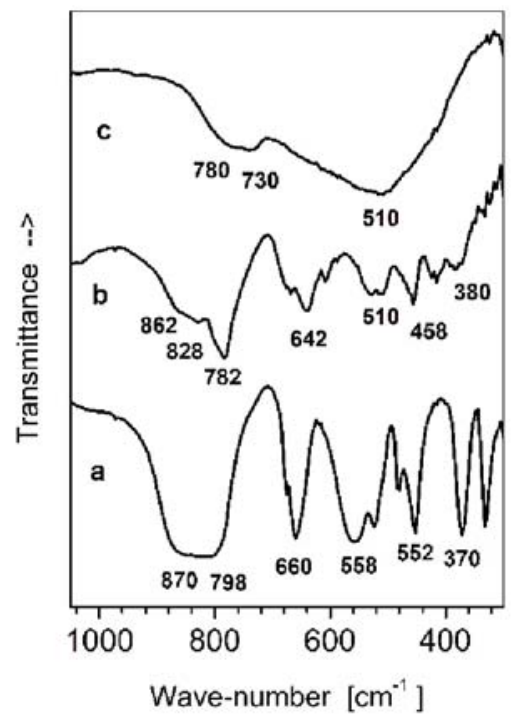

Figure 5. IR spectra of: a) $\gamma-\mathrm{LiAlO}_{2}$, b) $\beta-\mathrm{LiAlO}_{2}$, c) $\alpha-\mathrm{LiAlO}_{2}$

Figure 5 shows the IR spectra of $\gamma-\mathrm{LiAlO}_{2}$ (curve a), $\beta-\mathrm{LiAlO}_{2}$ (curve b) and $\alpha-\mathrm{LiAlO}_{2}$ (curve c). The literature survey has shown that crystal lattices of $\gamma-\mathrm{LiAlO}_{2}$ and $\beta-\mathrm{LiAlO}_{2}$ are built up of $\mathrm{LiO}_{4}$ and $\mathrm{AlO}_{4}$ tertahedra, when $\alpha-\mathrm{LiAlO}_{2}$ of $\mathrm{LiO}_{6}$ and $\mathrm{AlO}_{6}$ octahedra ${ }^{32,47,50-52}$. The presence of $\mathrm{LiO}_{4}$ and $\mathrm{AlO}_{4}$ tetrahedra in crystal lattices of $\gamma-\mathrm{LiAlO}_{2}$ (Fig. 5, curve a) and $\beta-\mathrm{LiAlO}_{2}$ (Fig. 5, curve b) with $\mathrm{Li}-\mathrm{O}$ and $\mathrm{Al}-\mathrm{O}$ bonds shorter than in the case of $\mathrm{LiO}_{6}$ and $\mathrm{AlO}_{6}$ octahedra is responsible for the shift of absorption bands in their spectra towards higher wavenumbers in comparison with the position of IR bands in the spectrum of $\alpha-\mathrm{LiAlO}_{2}$. Moreover, good agreement of the number and positions of absorption bands in IR spectrum of $\beta-\mathrm{LiAlO}_{2}$ obtained in our laboratory with data in paper ${ }^{35}$ corroborates that polymorph of $\mathrm{LiAlO}_{2}$ obtained by Chang crystallizes in an orthorhombic system.

\section{CONCLUSIONS}

Using applied procedures of syntheses, three phases have been obtained: $\alpha-\mathrm{LiAlO}_{2}, \beta-\mathrm{LiAlO}_{2}, \gamma-\mathrm{LiAlO}_{2}$.

A new method of $\mathrm{LiAlO}_{2}$ synthesis was developed consisting in grinding in mortar mixture of lithium carbonate and aluminum nitrate( $\mathrm{V})$ nonahydrate until the release of $\mathrm{CO}_{2}$ bubbles ceases and subsequent heating of obtained paste in the temperature range of $400-600{ }^{\circ} \mathrm{C}$.

As a result of the reaction of $\mathrm{LiOH} \mathrm{H} \mathrm{H}_{2} \mathrm{O}$ with $\mathrm{Al}_{2} \mathrm{O}_{3}$ sl, $\beta-\mathrm{LiAlO}_{2}$ was obtained, contaminated with a small amount of $\alpha-\mathrm{LiAO}_{2}$.

It has been shown that the powder diffractogram of the $\mathrm{Li}_{3} \mathrm{AO}_{3}$ phase is a set of diffraction reflections that can be attributed to the mixture of $\mathrm{LiOH}, \mathrm{Li}_{2} \mathrm{CO}_{3}$ and $\beta-\mathrm{LiAlO}_{2}$.

The results of XRD and IR investigations showed that $\beta$ - $\mathrm{LiAlO}_{2}$ crystallizes in an orthorhombic system.

\section{LITERATURE CITED}

1. Rebouças, L.B., Souza, M.T., Raupp-Pereira1, F., \& Novaes de Oliveira, A.P. (2019). Characterization of $\mathrm{Li}_{2} \mathrm{O}$ $-\mathrm{Al}_{2} \mathrm{O}_{3}-\mathrm{SiO}_{2}$ glass-ceramics produced from a Brazilian spodumene concentrate. Cerâmica 65, 366-377. DOI: 10.1590/036669132019653752699.

2. Ahmadi, Moghadam, H. \& Hossein, Paydar, M. (2016). The Effect of Nano $\mathrm{CuO}$ as Sintering Aid on Phase Formation, Microstructure and Properties of $\mathrm{Li}_{2} \mathrm{O}$-Stabilized $\beta^{\prime \prime}$-Alumina Ceramics. J. Ceram. Sci. Tech., 07(04), 441-446. DOI: 10.4416/ JCST2016-00075.

3. Shackelford, J.F. \& Doremus, R.H. (2008). Ceramic and glass materials. Structure, properties and processing. Springer Science+Business Media LLC New York. ISBN 978-0-38773361-6.

4. Dhabekar, B., Raja, E.A., Gundu Rao, T.K., Kher, R.K. \& Bhat, B.C. (2009). Thermoluminescence, optically stimulated luminescence and ESR studies on $\mathrm{LiAl}_{5} \mathrm{O}_{8}$ :Tb. Indian. J. Pure Ap. Phy., 47, 426-428.

5. Mandowska, E., Mandowski, A., Bilski, P., Marczewska, B., Twardak, A. \& Gieszczyk, W. (2015). Lithium aluminate a new detector for dosimetry. Prz. Elektrotech. 91(9), 117-120 (in Polish).

6. Gao, J., Shi, S., Xiao, R. \& Li, H. (2016). Synthesis and ionic transport mechanisms of $\alpha-\mathrm{LiAlO}_{2}$, Solid State Ionics, 286, 122-134. DOI: 10.1016/j.ssi.2015.12.028.

7. Özkan, G. \& Incirkuş Ergençoglu, V. (2016). Synthesis and characterization of solid electrolyte structure material $\left(\mathrm{LiAlO}_{2}\right)$ using different kinds of lithium and aluminum compounds for molten carbonate fuel cells. Indian J. Chem. Technol. 23, 227-231.

8. Kim, J.E., Patil, K.Y., Han, J., Yoon, S.P., Nam, S.W., Lim, T.H., Hong, S.A., Kim, H. \& Lim, H.Ch. (2009). Using aluminum and $\mathrm{Li}_{2} \mathrm{CO}_{3}$ particles to reinforce the $\alpha-\mathrm{LiAlO}_{2}$ matrix for molten carbonate fuel cells. Internat. J. Hydrogen Energy 34(22), 9227-9232. DOI: 10.1016/j.ijhydene.2009.08.069.

9. Ducan, Y. (2021). Theoretical Investigation of the $\mathrm{CO}_{2}$ Capture Properties of $\gamma-\mathrm{LiAlO}_{2}$ and $\alpha-\mathrm{Li}_{5} \mathrm{AlO}_{4}$. Micro Nanosyst. 13, 32-41. DOI: 10.2174/187640291166619091318 4300.

10. Ávalos-Rendón, T., Casa-Madrid, J. \& Pfeiffer, H. (2009). Thermochemical Capture of Carbon Dioxide on Lithium Aluminates $\left(\mathrm{LiAlO}_{2}\right.$ and $\left.\mathrm{Li}_{5} \mathrm{AlO}_{4}\right)$ : A New Option for the $\mathrm{CO}_{2}$ Absorption. J. Phys. Chem. A, 113, 6919-6923. DOI: 10.1021/ jp902501v.

11. Raja, M., Sanjeev, G., Kumar, T.P. \& Stephan, A.M. (2015). Lithium aluminate-based ceramic membranes as separators for lithium-ion batteries. Ceram. Int. 41, 3045-50. DOI: 10.1016/j.ceramint.2014.10.142.

12. Fouad, O.A., Farghaly, F.I. \& Bahgat, M. (2007). A novel approach for synthesis of nanocrystalline $\gamma-\mathrm{LiAlO}_{2}$ from spent lithium-ion batteries. J. Anal. Appl. Pyrolysis. 78, 65-69. DOI: 10.1016/j.jaap.2006.04.002.

13. Pollard, V.A., Young, A., McLellan, R., Kennedy, A.R., Tuttle, T., Robert, E. \& Mulvey, R.E. (2019). Lithium-Aluminate-Catalyzed Hydrophosphination Applications. Angew. Chem. Int. Ed. 58, 1229-12296. DOI: 10.1002/anie.201906807.

14. Indris, S. \& Heitjans, P. (2006). Local electronic structure in a $\mathrm{LiAlO}_{2}$ single crystal studied with ${ }^{7} \mathrm{Li}$ NMR spectroscopy and comparison with quantum chemical calculations. Phys. Rev. B 74, 245120-1-5. DOI: 10.1103/PhysRevB.74.245120.

15. Duan, Y., Sorescu, D.C., Jiang, W. \& Senor, D.J. (2020) Theoretical study of the electronic, thermodynamic, and thermo-conductive properties of $\gamma-\mathrm{LiAlO}_{2}$ with ${ }^{6} \mathrm{Li}$ isotope substitutions fortritium production. J. Nucl. Mater. 530, 151963. DOI: 10.1016/j.nucmat.2019.151963.

16. Rasneur, B. (1985). Tritium breeding material $\gamma-\mathrm{LiAlO}_{2}$. Fusion Technol. 8, 1909-1914. DOI: 10.13182/FST85-A40040. 
17. Liu, Y.Y., Billone, M.C., Fischer, A.K., Tam, S.W., Clemmer, R.G. \& Hollenberg, G.W. (1985). Solid tritium breeder materials $\mathrm{Li}_{2} \mathrm{O}$ and $\mathrm{LiAlO}_{2}$ - a data-base review. Fusion Sci. Technol. 8, 1970-1984. DOI: 10.13182/FST85-A24573.

18. Morley, N.B., Abdou, M.A., Anderson, M., Calderoni, P., Kurtz, R.J., Nygren, R., Raffray, R., Sawan, M., Sharpe, P., Smolentsev, S., Willms, S. \& Ying, A.Y. (2006). Overview of fusion nuclear technology in the US. Fusion Eng. Des. 81, 33-43. DOI: 10.1016/j.fusengdes.2005.06.359.

19. Strickler, D.W. \& Roy, R. (1961). Studies in the System $\mathrm{Li}_{2} \mathrm{O}-\mathrm{Al}_{2} \mathrm{O}_{3}-\mathrm{Fe}_{2} \mathrm{O}_{3}-\mathrm{H}_{2} \mathrm{O}$. J. Am. Ceram. Soc. 44, 5, 225-230. DOI: 10.1111/j.1151-2916.1961.tb15365.x.

20. Lejus, A.M. \& R. Collongues, R. (1962). Sur la structure les propriétés des aluminates de lithium. Chimie Minérale 2005-2007.

21. Kriens, M., Adiwidjaja, G., Guse, W., Klaska, K.H., Lathe, C. \& Saalfeld, H. (1996). The crystal structures of $\mathrm{LiAl}_{5} \mathrm{O}_{8}$ and $\mathrm{Li}_{2} \mathrm{Al}_{4} \mathrm{O}_{7}$. N. Jb. Miner. Mh. 8, 344-350.

22. Hatch, R.A. (1943). Phase equilibrium in the system: $\mathrm{Li}_{2} \mathrm{O}-\mathrm{Al}_{2} \mathrm{O}_{3}-\mathrm{SiO}_{2}$. Am. Mineral. 28, 471-496. DOI: 10.1111/ j.1151-2916.1985.tb15280.x.

23. Cook, L.P. \& Plante, E.R. (1992). Phase Diagram of the System $\mathrm{Li}_{2} \mathrm{O}-\mathrm{Al}_{2} \mathrm{O}_{3}$. Ceram. Trans. 27, 193-222.

24. Byker, H.J., Eliezer, I., Eliezer, N. \& Howald, R.A. (1979). Calculation of a Phase Diagram for $\mathrm{LiO}_{0.5}-\mathrm{AlO}_{1.5}$ System. $J$. Phys. Chem. 83, 18, 2349-2355. DOI: 10.1021/j100481a009.

25. Konar, B., Van Ende, M.A. \& Junh, I.H. (2018). Critical Evaluation and Thermodynamic Optimization of the $\mathrm{Li}_{2} \mathrm{O}$ $\mathrm{Al}_{2} \mathrm{O}_{3}$ and $\mathrm{Li}_{2} \mathrm{O}-\mathrm{MgO}-\mathrm{Al}_{2} \mathrm{O}_{3}$ Systems. Metall. Mat. Trans. B 49, 2917-2944. DOI: 10.1007/s11663-018-1349-x.

26. Marezio, M. \& Remeika, J.P. (1966). High-pressure synthesis and crystal srtucture of $\alpha-\mathrm{LiAlO}_{2}$. J. Chem. Phys. 44, 3143-4. DOI: 10.1063/1.1727203.

27. Lehmann, H.A. \& Hesselbrarth, H.Z. (1961). Uber eine neue Modifikation des $\mathrm{LiAlO}_{2}$. Anorg. Allg. Chem. 313, 117-120. DOI: 10.1002/zaac.19613130110.

28. Dronskowski, R. (1993). Reactivity and acidity of Li in $\mathrm{LiAlO}_{2}$ phases. Inorg. Chem. 32, 1-9. DOI: 10.1021/ic00053a001.

29. Poepplmeler, K.R., Chiang, C.K. \& Kipp, D.O. (1988). Synthesis of High-Surface-Area $\alpha-\mathrm{LiAlO}_{2}$. Inorg. Chem. 27, 4523-4524. DOI: 10.1021/ic00298a002.

30. Thery, J. (1961). Structure and properties of alkaline aluminates. Bull. Soc. Chim. Fr. 973-5.

31. Marezio, M. (1965). The Crystal Structure of $\mathrm{LiGaO}_{2}$ Acta Cryst. 18, 481-484. DOI: 10.1107/S0365110X65001068.

32. Marezio, M. (1965). The Crystal Structure and Anomalous Dispersion of $\gamma-\mathrm{LiAlO}_{2}$. Acta Cryst. 19, 396-400. DOI: 10.1107/S0365110X65003511.

33. Li, X., Kobayashi, T., Zhang, F., Kimoto, K. \& Sekine, T. (2004). A new high-pressure phase of $\mathrm{LiAlO}_{2}$. J. Solid State Chem. 177, 1939-1943. DOI: 10.1016/j.jssc.2003.12.014.

34. Lei, L., He, D., Zou, Y. \& Zhang, W. (2008). Phase transitions of $\mathrm{LiAlO}_{2}$ at high pressure and high temperature. J. Solid State Chem. 181, 1810-1815. DOI: 10.1016/j.jssc.2008.04.006.

35. Chang, C.H. \& Margrave, J.L. (1968). Highpressure-high temperature synthesis. III. Direct synthesis of new high-pressure forms of $\mathrm{LiAlO}_{2}$ and $\mathrm{LiGaO}_{2}$ and polymorphism in $\mathrm{LiMO}_{2}$ compounds $(\mathrm{M}=\mathrm{B}, \mathrm{Al}, \mathrm{Ga})$. J. Amer. Chem. Soc. 90 , 2020-2022. DOI: 10.1021/ja01010a018.

36. Debray, L. \& Hardy, A.C.R. (1960). Contribution a Vetude structurale des aluminates de lithium. Hebd. Seances Acad. Sci. 251, 725-726.

37. Waltereit, P., Brandt, O., Trampert, A., Grahn, H.T., Menniger, J., Ramsteiner, M.,M. Reiche, M. \& Ploog, K.H. (2000). Nitride semiconductors free of electrostatic fields for efficient white light-emitting diodes. Nature 406, 865-868. DOI: $10.1038 / 35022529$

38. Wiedemann, D., Indris, S., Meyen, M. \& Pedersen, B. (2016) Single-crystal neutron diffraction on $\gamma-\mathrm{LiAlO}_{2}$ : Structure determination and estimation of lithium diffusion pathway.
Zeitschrift für Kristallographie - Crystalline Materials. 231(3), 189-193. DOI: 10.14279/depositonce-5480.

39. Ha, N.T.T., Van Giap, T. \& Thanh, N.T. (2020). Synthesis of lithium aluminate for application in radiation dosimetry. Mater. Lett. 267, 127506. DOI: 10.1016/j.matlet.2020.127506.

40. Jimenez-Becerril, J. \& Garcia-Sosa, I. (2011). Synthesis of lithium aluminate by thermal decomposition of a lithium dawsonite-type precursor. J. Ceram. Process. Res. 12, 52-56.

41. Heo, S.J., Batra, R., Ramprasad, R. \& Singh, P. (2018). Crystal morphology and phase transformation of $\mathrm{LiAlO}_{2}$ : combined experimental and first-principles Studies. J. Phys. Chem. C 222, 28797-28804. DOI: 10.1021/acs.jpcc.8b09716.

42. Patil, K.Y., Yoon, S.P., Han, J., Lim, T.H., Nam, S.W. \& Oh, I.H. (2011). The effect of lithium addition on aluminumreinforced $\alpha-\mathrm{LiAlO}_{2}$ matrices for molten carbonate fuel cells. Int. J. Hydrog. Energy, 36, 6237-6247. DOI: 10.1016/j. ijhydene.2011.01.161.

43. Park, J.S., Meng, X., Elam, J.W., Hao, S., Wolverton, Ch., Kim, Ch. \& Cabana, J. (2014). Ultrathin Lithium-Ion Conducting Coatings for Increased Interfacial Stability in High Voltage Lithium-Ion Batteries. Chem. Mater. 26, 3128-3134. DOI: $10.1021 / \mathrm{cm} 500512 \mathrm{n}$.

44. Cheng, F., Xin, Y., Huang, Y., Chen, J., Zhou, H. \& Zhang, X. (2013). Enhanced electrochemical performances of $5 \mathrm{~V}$ spinel $\mathrm{LiMn}_{1.58} \mathrm{Ni}_{0.42} \mathrm{O}_{4}$ cathode materials by coating with $\mathrm{LiAlO}_{2}$. J. Power Sources. 239, 181-188. DOI: 10.1016/j. jpowsour.2013.03.143.

45. Cao, H., Xia, B., Zhang, Y., Xu, N. (2005). LiAlO -coated $\mathrm{LiCoO}_{2}$ as cathode material for lithium ion batteries. Solid State Ionics. 176, 911-914. DOI: 10.1016/j.ssi.2004.12.001.

46. Danek, V., Tarniowy, M. \& Suski, L. (2004) Kinetics of the $\alpha \rightarrow \gamma$ phase transformation in $\mathrm{LiAlO}_{2}$ under various atmospheres within the 1073-1173 K temperatures range. J. Mater. Sci. 39, 2429-2435. DOI: 10.1023/B:JM SC.0000020006.46296.04.

47. Lejus, A.M. (1964). Sur la formation a haute temperature de spinelles non stechiométriques et de phases derivées dans plusieurs systémes d'oxydes a base d'alumina et dans le systéme alumina-nitrure d'aluminum. Rev. Hautes Tempér. et Réfract., 1, 53-95.

48. Hummel, F.A., Sastry, B.S.R. \& Wotring, D. (1958). Studies in Lithium Oxide Systems: II, $\mathrm{Li}_{2} \mathrm{O} \cdot \mathrm{Al}_{2} \mathrm{O}_{3}-\mathrm{Al}_{2} \mathrm{O}_{3}$. J. Am. Ceram. Soc. 41, 3, 88-92. DOI: 10.1111/j.1151-916.1958. tb15448.x.

49. Isupov, V.P., Bulina, N.V. \& Borodulina, I.A. (2017). Effect of Water Vapor Pressure on the Phase Composition of Lithium Monoaluminates Formed in the Interaction of Aluminum Hydroxide and Lithium Carbonate. Zhurnal Prikladnoi Khimii, 90, 986-991. DOI: 10.1134/S1070427217080043.

50. Tarte, P. (1967). Infra-red spectra of inorganic aluminates and characteristic vibrational frequencies of $\mathrm{AlO}_{4}$ tetrahedra and $\mathrm{AlO}_{6}$ octahedra. Spectrochim. Acta 23A, 2127-2143. DOI: 10.1016/0584-8539(67)80100-4.

51. Braun, P.A. (1952). Superstructure in Spinels. Nature 170, 1123. DOI: $10.1038 / 1701123 \mathrm{a} 0$.

52. Datta, R.K. \& Roy, R. (1963). Phase Transitions in $\mathrm{LiAl}_{5} \mathrm{O}_{8}$. J. Am. Ceram. Soc. 46, 8, 388-390. DOI: 10.1111/j.11512916.1963.tb11757.x.

53. La Ginestra, A., Lo Jacono, M. \& Porta, P. (1972). The preparation, characterization, and thermal behaviour of some lithium aluminum oxides: $\mathrm{Li}_{3} \mathrm{AlO}_{3}$ and $\mathrm{Li}_{5} \mathrm{AlO}_{4}$. J. Thermal Anal. 4, 5-17. DOI: 10.1007/bf02100945.

54. Kroger, C. \& Fingas, E. (1935). Über die Systeme Alkalioxyd-CaO- $\mathrm{Al}_{2} \mathrm{O}_{3}-\mathrm{SiO}_{2}-\mathrm{CO}_{2}$. IV. Die $\mathrm{CO}_{2}$-Drucke des kieselsäurereicheren Teils des Systems $\mathrm{Li}_{2} \mathrm{O}-\mathrm{SiO}_{2}-\mathrm{CO}_{2}$ und der Einwirkung von $\mathrm{Al}_{2} \mathrm{O}_{3}$ auf $\mathrm{Li}_{2} \mathrm{CO}_{3}$. $\mathrm{Z}$ anorg. Allg. Chem. 224, 289-304. DOI: 10.1002/zaac.19352240309.

55. Fedorov, T.F. \& Shamari, F.I. (1960). Prim. Vak. V. Met., Akad. Nauk SSSR, Inst. Met. A.A. Baikova, 137-142. 
56. Walczak, J., Kurzawa, M. \& Tabero, P. (1987). $\mathrm{V}_{9} \mathrm{Mo}_{6} \mathrm{O}_{40}$ and phase equilibria in the system $\mathrm{V}_{9} \mathrm{Mo}_{6} \mathrm{O}_{40}-\mathrm{Fe}_{2} \mathrm{O}_{3}$. Thermochim. Acta 118, 1-7. DOI: 10.1016/0040-6031(87)80065-5.

57. Tabero, P. (2010). Formation and properties of the new $\mathrm{Al}_{8} \mathrm{~V}_{10} \mathrm{~W}_{16} \mathrm{O}_{85}$ and $\mathrm{Fe}_{8-\mathrm{x}} \mathrm{Al}_{\mathrm{x}} \mathrm{V}_{10} \mathrm{~W}_{16} \mathrm{O}_{85}$ phases with the $\mathrm{M}-\mathrm{Nb}_{2} \mathrm{O}_{5}$ structure. J. Therm. Anal. Calorim. 101, 560-566. DOI: 10.1007/ s10973-010-0848-z.

58. Tabero, P., Frackowiak, A., Filipek, E., Dąbrowska, G., Homonnay, Z. \& Szilágyi, P.Á. (2018). Synthesis, thermal stability and unknown properties of $\mathrm{Fe}_{1-\mathrm{x}} \mathrm{Al}_{\mathrm{x}} \mathrm{VO}_{4}$ solid solution. Ceram. Int. 44, 17759-17766. DOI: 10.1016/j.ceramint.2018.06.243.

59. Filipek, E., Dabrowska, G. \& Piz, M. (2010). Synthesis and characterization of new compound in the V-Fe-Sb-O system. $J$. Alloys Compd. 490, 93-97. DOI: 10.1016/j.jallcom.2009.10.123.

60. Levin, I. \& Brandon, D. (1998). Metastable Alumina Polymorphs: Crystal Structures and Transition Sequences. J.
Am. Ceram. Soc. 81, 1995-2012. DOI: 10.1111/j.1151-2916.1998. tb02581.x.

61. Krokodis, X., Raybaud, P., Gobichon, A.E., Rebours, B., Euzen, P. \& Toulhoat, H. (2001). Theoretical Study of the Dehydration Process of Boehmite to $\gamma$-Alumina. J. Phys. Chem. B 105, 5121-5130. DOI: 10.1021/jp0038310.

62. Kim, J., Kang, H., Hwang, K. \& Yoon, S. (2019). Thermal Decomposition Study on $\mathrm{Li}_{2} \mathrm{O}_{2}$ for $\mathrm{Li}_{2} \mathrm{NiO}_{2}$ Synthesis as a Sacrificing Positive Additive of Lithium-Ion Batteries. Molecules 24, 4624-4632. DOI: 10.3390/molecules24244624.

63. Tovar, T.M. \& Le, Van, M.D. (2017). Supported lithium hydroxide for carbon dioxide adsorption in water-saturated environments. Adsorption 23, 51-56. DOI: 10.1007/s10450016-9817-6. 